\title{
WHAT IS THE INFLUENCE OF ACTIVELY ENGAGING STUDENTS WITH LEARNING PROCESS ON STUDENTS' SUCCESS? AN EXPERIMENTAL RESEARCH IN GEOGRAPHY EDUCATION
}

DOI: http://dx.doi.org/10.18509/GBP.2015.59

UDC: $373.5 .091 .3 / 910.1$

\author{
Assoc. Prof. Dr. Fikret TUNA \\ Fatih University, Dept. of Geography, Istanbul - Turkey.
}

\begin{abstract}
Today, educators worldwide have recognized the limits of traditional teaching methods and initiated reform movements in education. Actively engaging students with learning process or active learning is one of the approaches that have the basic principles of constructivist approach to student learning. It has been perceived as a radical change from traditional instruction and has received considerable attention over the past several years. The importance of using constructivist approach and active learning methods in geography courses has been referred for especially a decade. However, there is a need of determining the impacts of different active learning methods on students' academic achievement. The aim of this study is to reveal the influence of actively engaging students with learning process on students' academic achievement in secondary geography education. Two different active learning activities including the use of "smart board" and the use of "everyone is a teacher here method" were conducted in secondary geography lectures. Implementations were done in a pretest posttest experimental research model with control groups. The positive effects on students' achievement and students' positive perceptions about the methods were identified after analyzing the data statistically.
\end{abstract}

Keywords: Active learning, geography education, everyone is a teacher here, smart board.

\section{INTRODUCTION}

Since there is a greater need than ever for individuals who have independent, critical, and effective thinking skills; that is, they can solve problems by using analysis and synthesis, take responsibility for decision making, are eager for lifelong learning, take part in teamwork, have effective communication skills, and possess democratic attitudes and behaviours in today's world, education has experienced changes in mindset and training methods [1]. Educators worldwide have recognized the limits of traditional teaching methods and initiated reform movements in education [2].

One of the reforms in education is constructivist learning, an approach bringing a new perspective to learning. The constructivist theories which are traced to Dewey and some others in teaching and learning are popular among educational studies and constructivist pedagogy's advocates contrast 'traditional' methods which are characterized in several ways including 'chalk and talk' to describe lectures and 'drill and kill' for homework [3]. So, the adoption of a constructivist approach in geography courses has been accorded great importance in the world [4].

Active learning is one of the approaches that have the basic principles of constructivism to student learning. It is a teaching approach in which learning is encouraged by actively engaging with the learning process, or put more simply, learning through doing. So, it is 
an instructional strategy that contrasts with traditional approaches in which teachers do most of the work while students are passive receptors of knowledge $[1,5,6,7,8]$. So, it has been perceived as a radical change from traditional instruction and has received considerable attention over the past several years $[9,10]$.

The importance of using a constructivist approach and active learning methods in geography courses has been referred to in some studies and the findings of some studies have indicated that active learning methods and techniques make a positive contribution to geography education $[10,11,12]$. However, new studies should be conducted to disseminate the use of active learning methods in geography by testing the impacts of different active learning methods and techniques on students' academic achievement and learning in geography education. For this purpose, the following questions were researched: (1) What are the impacts of active learning methods on students' academic achievement in higher geography education? (2) And, what are students' evaluations of active learning methods?

\section{METHODOLOGY}

The study included a total of 112, secondary geography students of two schools which were situated in Istanbul. Of the students participated in the study, 54 was male $(48.21 \%)$ and 58 were female (51.79\%). Also, 51 were in experiment group (45.54\%) and 61 were in control group (54.46\%). Moreover, of these students, 44 were in school A $(39.29 \%)$ and 68 were in school B $(60.71 \%)$ (Table 1$)$.

Table 1. Distribution of participants by gender, groups and schools

\begin{tabular}{llll}
\hline Variable & & $\mathbf{n}$ & $\mathbf{\%}$ \\
\hline \multirow{2}{*}{ Gender } & Male & 54 & 48.2 \\
\cline { 2 - 4 } & Female & 58 & 51.8 \\
\hline \multirow{2}{*}{ Groups } & Experiment Group & 51 & 45.5 \\
\cline { 2 - 4 } & Control Group & 61 & 54.5 \\
\hline \multirow{2}{*}{ Schools } & School A & 44 & 39.3 \\
\cline { 2 - 4 } & School B & 68 & 60.7 \\
\hline Total & Total & 112 & 100.0 \\
\hline
\end{tabular}

The study was conducted in three sequenced phases of preparation, implementation and evaluation. In preparation phase, the methods that will be used in the study were determined and the needs -the planning of the activities and the preparation of achievement test and evaluation survey- were prepared. The survey consisted of 9 statements. The students' responses were taken on the basis of a five-point Likert scale ( $1=$ strongly disagree; $2=$ disagree; $3=$ neutral; $4=$ =agree; $5=$ strongly agree).

In the implementation phase, a total of two experiment and two control groups from two different universities participated in the study. The active learning activities were conducted in the randomly selected experiment groups in two-hour lectures. The study was designed according to "pre-test-post-test experimental research model with control group". Both in experiment and control groups, the achievement tests were conducted before (pre-test) and after (post-test) the active learning activities. In addition, evaluation surveys were conducted in experiment groups in order to reveal students' evaluations about active learning activities. The experimental design of the study was given in Table 2. 
Table 2. Experimental design of the study

\begin{tabular}{llll}
\hline Groups & Pre-test & Teaching method & Post-test \\
\hline Experiment group & Achievement test & $\begin{array}{l}\text { Active learning } \\
\text { activities }\end{array}$ & $\begin{array}{l}\text { Achievement test } \\
\text { Evaluation survey }\end{array}$ \\
\hline Control group & Achievement test & Ordinary teaching & Achievement test \\
\hline
\end{tabular}

One of the active learning implementations included the use of activities by "using smart board in geography lecture". By using smart board in the geography lecture, an interactive presentation, a video watching, a pop quiz, a matching game and a crossword activity were conducted in the experiment group. On the other hand, the other active learning implementation, in the other school, included an active learning method called "everyone is a teacher here". In this method, the students were given blank papers and asked to write questions about the lecture while the teacher was teaching. Then, the papers were collected from the students and redistributed randomly. The students, then, were wanted to answer the questions written on the paper in their hands.

The reliability coefficient was $81 \%$ based on the factor reliability analysis of dependent variables (Cronbach's alpha $=0.810$ ). In the study, descriptive statistics were used for demographic data and non-parametric tests were used, including the Mann-Whitney U, Wilcoxon Signed Ranks Test and Regression Analysis, for the inferential statistics, because the data did not have a normally distributed interval variable according to a onesample Kolmogorov-Smirnov test $(\mathrm{P}<0.05)$.

\section{FINDINGS}

In order to determine whether the pre-test scores of experiment and control groups differed significantly, the Mann-Whitney $U$ test was performed and no statistically significant difference was found between the groups $(\mathrm{p}>0.05)$. Accordingly, students started to the study with no important knowledge difference about the subject that will be taught (Table 2).

In addition, in order to determine whether the post-test scores of experiment and control groups differed significantly, the Mann-Whitney U test was performed again and this time statistically significant difference was found between the groups $(\mathrm{p}<0.05)$. The results indicated that there appeared a statistically significant difference between experiment and control groups at the end (Table 3).

Table 3. Mann-whitney u test results about experiment and control groups

\begin{tabular}{|c|c|c|c|c|c|c|c|c|}
\hline \multirow{2}{*}{$\begin{array}{l}\text { Method } \\
\text { Test }\end{array}$} & \multicolumn{4}{|c|}{ Smart board } & \multicolumn{4}{|c|}{ Everyone is a teacher here } \\
\hline & Pre-test & & Post-test & & Pre-test & & Post-test & \\
\hline Groups & Exprmnt & Control & Exprmnt & Control & Exprmnt & Control & Exprmnt & Control \\
\hline $\mathrm{N}$ & 24 & 20 & 24 & 20 & 27 & 41 & 27 & 41 \\
\hline $\begin{array}{l}\text { Mean } \\
\text { Rank }\end{array}$ & 22.56 & 22.43 & 26.98 & 17.13 & 32.09 & 36.09 & 43.72 & 28.43 \\
\hline $\begin{array}{l}\text { Sum of } \\
\text { Ranks }\end{array}$ & 541.5 & 448.5 & 647.5 & 342.5 & 866.5 & 1479.5 & 1180.5 & 1165.5 \\
\hline $\mathrm{U}$ & 238.500 & & 132.500 & & 488.500 & & 304.500 & \\
\hline $\mathrm{Z}$ & -0.036 & & -2.546 & & $-0-819$ & & -3.130 & \\
\hline $\mathrm{p}$ & 0.971 & & 0.011 & & 0.413 & & 0.022 & \\
\hline
\end{tabular}

Moreover, in order to determine whether active learning activities increased the academic achievement of the students significantly, the "Wilcoxon Signed Ranks Test" was 
performed between pretest and posttest scores. The analysis of the responses (shown in Table 3) indicates that pretest and posttest scores of experiment groups differed significantly $(\mathrm{z}=-8.827, \mathrm{p}=0.000)$. When mean ranks are considered, this difference also revealed the increase towards posttest (Table 4).

Table 4. Wilcoxon signed ranks test results

\begin{tabular}{lllll}
\hline Method & Mean Rank & Sum of Ranks & $\mathbf{Z}$ & $\mathbf{p}$ \\
\cline { 1 - 3 } Pre-test & 12.40 & 124.00 & -8.827 & \multirow{2}{*}{0.000} \\
\hline Post-test & 60.82 & 6204.00 & & \\
\hline
\end{tabular}

The positive effects of active learning (using smart board and everyone is a teacher here methods) on the academic achievement of students were also understood from figure 1 besides Mann-Whitney U and Wilcoxon Signed Rank tests. Accordingly, the average knowledge level of students in the experiment group in which smart board was used increased from 1.59 to 9.15 . On the other hand, average knowledge level increased from 1.61 to 6.63 in control group. In addition, in the experiment group of everyone is a teacher here, the average knowledge level increased from 1.33 to 7.84 while it increased from 1.63 to 5.11 in control group (Figure 1).

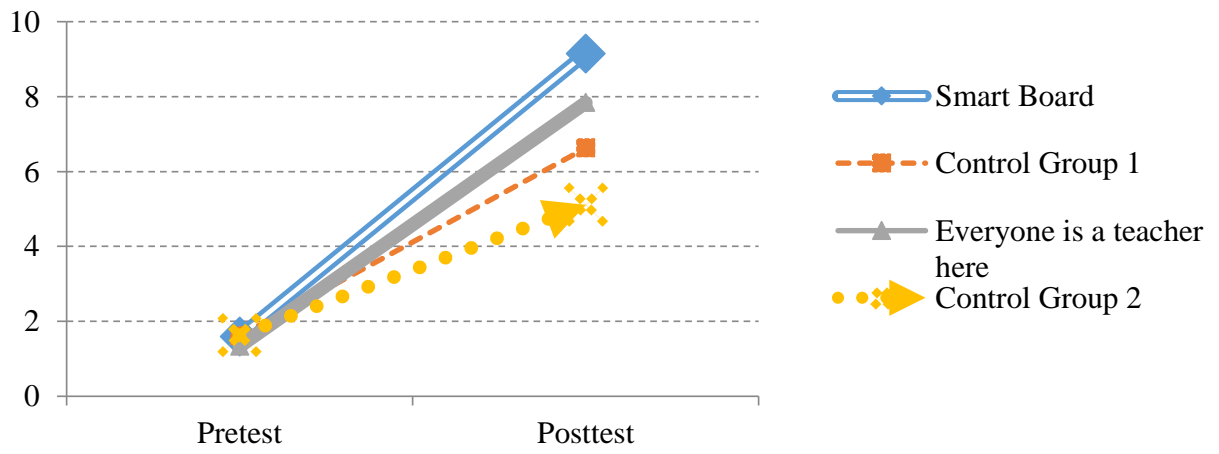

Figure 1. The change of academic achievement averages in groups

The findings revealed that both of the active learning methods increased the academic achievement of the students significantly compared to ordinary teaching (includes passive learning methods). In addition, the results of the regression analysis, which was performed in order to understand the share of the methods on achievement, also showed that $16 \%$ of the students' achievement in experiment groups was the contributions of active learning (Table 5).

Table 5. The results of regression analysis

\begin{tabular}{ccccc}
\hline Model & R & R2 & Adjusted R2 & Standard Error of The Estimate \\
\hline 1 & 0.402 & 0.161 & 0.154 & 1.08236 \\
\hline
\end{tabular}

The results of evaluation surveys which were conducted just after completing the active learning activities in experiment groups revealed students' very positive perceptions about active learning. It was quite encouraging in the sense that, the average grade observed as 4.44, corresponding to "agree". Four of the statements reached "strongly agree" level and remaining five statements were at "agree" level. There was no statement about which students stated, "neutral", "disagree" and "strongly disagree" if the average scores were taken into account. The statements in which students had higher scores, corresponding to "strongly agree", were "I fully joined in the activity" (4.65), "The 
activity made me think more about the subject" (4.61), "This activity is necessary to use in geography lectures" (4.59) and "The activity helped me to understand the subject better" (4.55). All the statements and their average scores were given in Table 6.

Table 6. The average grades of statements in evaluation survey

\begin{tabular}{ll}
\hline Statements & Mean \\
\hline I fully joined in the activity. & 4.65 \\
\hline The activity made me think more about the subject. & 4.61 \\
\hline This activity is necessary to use in geography lectures. & 4.59 \\
\hline The activity helped me to understand the subject better. & 4.55 \\
\hline The activity increased my interest to geography lectures. & 4.47 \\
\hline I think the information will persist for a long time. & 4.37 \\
\hline The activity increased my curiosity about geography subjects. & 4.37 \\
\hline The activity helped me to ask questions easily. & 4.33 \\
\hline It was easy to join in the activity. & 4.04 \\
\hline Average & 4.44 \\
\hline
\end{tabular}

\section{RESULTS}

With this study, two important samples for the use of active learning methods in geography teaching were presented. The positive influence of actively engaging students with learning process (here the use of "smart boards" and the technique of "everyone is a teacher here") on students" academic achievement were identified. It was revealed that the active learning makes more contribution to the achievement than traditional teaching methods and lecturing do. In the comparison of two groups with nearly same levels of initial knowledge, the average achievement level of students in active learning group increased more than the normal group after the lectures. In addition, the contribution of actively engaging students with learning process was found as $16 \%$ as a result of analysis. So, active learning can be considered as one of the effective methods that enhance students' academic achievement.

Besides, the students' perceptions about the use of active learning were very positive. They participated in the activities easily. The average assessment rate of the activities was 4.44 out of 5.00, which corresponded to "agree". The students thought that the active learning methods had increased their thinking, learning and asking skills and affected their interest to geography and curiosity about the subjects in a positive way. Moreover, they strongly agreed that these or similar methods should be used in geography lectures commonly.

In conclusion, active learning methods should be given more space in different grades of the higher geography lectures. In this wise, the contribution to the expansion of active learning methods, which are based on constructivist approach, would be provided in geography education. Thus, rather than recite lectures in geography; exploring, deeply thinking and analyzing skills would be developed. In this way, the contribution of geography education in teaching students the skills needed in today's societies would be provided. Also, the place of geography education in the community would be brought to the desired level. So, some key steps should be taken by authorized institutions to make the active learning methods more widespread. 


\section{REFERENCES}

[1] Tuna, F. Current situation and analysis of geography teachers' active learning knowledge and usage in Turkey, Educational Research and Reviews, vol. 7(18), pp 393400, 2012. DOI: $10.5897 /$ ERR12.047

[2] Tuna, F. What do students have in their mental maps about the concept of migration? An analysis from Turkey. The International Journal of Social Sciences, vol. 9(1), pp 6370, 2013.

[3] Schweitzer, L. \& Stephenson, M. Charting the challenges and paradoxes of constructivism: a view from professional education, Teaching in Higher Education, vol. 13(5), pp 583-593, 2008.

[4] Tuna, F. \& Kılınç, Y. How do undergraduate geography students perceive the concept "the structure of the earth"? A phenomenographic study, International Journal of Science and Advanced Technology, vol. 2(11), pp 11-15, 2012.

[5] Bonwell, C.C. \& Eison, J.A. Active learning: creating excitement in the classroom, ASHE-ERIC Higher Education Report no. 1, Washington, DC: George Washington University, 1991.

[6] Meyers, C. \& Jones, T.B. Promoting active learning: strategies for the college classroom, San Francisco: Jossey-Bass, 1992.

[7] Rotgans JI \& Schmidt H.G. Situational interest and academic achievement in the active-learning classroom, Learning Instruction, vol. 21, pp 58-67, 2011.

[8] Scheyvens, R. \& Griffin, A.L. \& Jocoy, C.L. \& Liu, Y. \& Bradford, M. Experimenting with active learning in geography: dispelling the myths that perpetuate resistance, Journal of Geography in Higher Education, vol. 32(1), pp 51-69, 2008.

[9] Açıkgöz, K. Active learning. İzmir: Biliş Press, 2007.

[10] Tuna, F. Students' perspectives on active learning in geography: a case study of level of interest and usage in Turkey, European Journal of Educational Studies, vol. 4(2), pp 163-176, 2012.

[11] Bekmezci, B. \& Ünlü, M. The effect of students' success, using the method of groupwork in geography education, Marmara Geographical Review, vol. 16, pp 53-62, 2007. [12] Köseoğlu, İ. \& Ünlü, M. The effect of drama technique in geography lecture, Marmara Geographical Review, vol. 13, pp 125-132, 2006. 